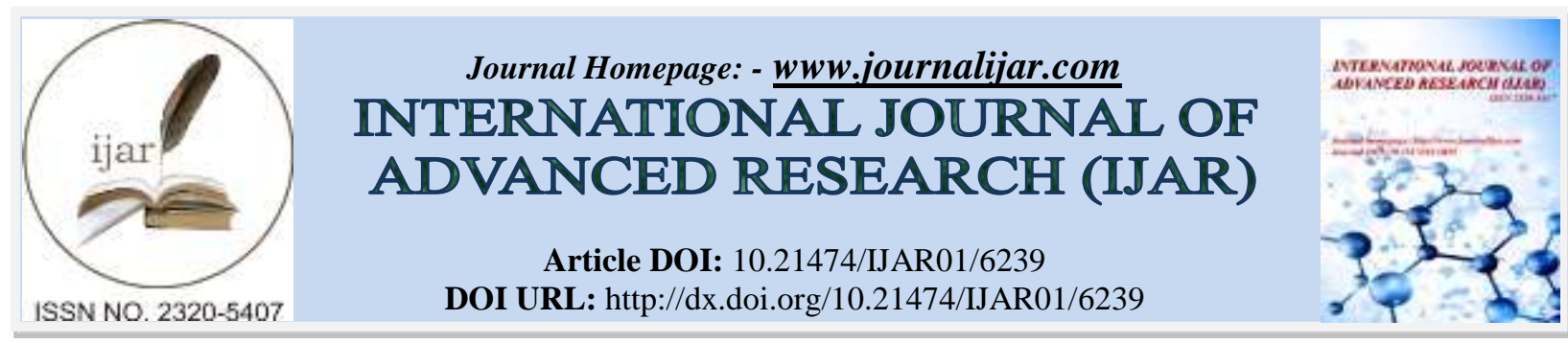

RESEARCH ARTICLE

\title{
PATH CO-EFFICIENT ANALYSIS IN OKRA [ABELMOSCHUS ESCULENTUS (L.) MOENCH].
}

\author{
Archana Mishra ${ }^{1}$, H. N. Mishra ${ }^{1}$, N. Senapati ${ }^{2}$ and P. Tripathy ${ }^{1}$ \\ 1. Department of Vegetable Science, College of Agriculture. \\ 2. Associate Director of Research (OUAT), Semiliguda, Koraput, Odisha. Orissa University of Agriculture and \\ Technology, Odisha-751003, India.
}

\section{Manuscript Info}

Manuscript History

Received: 06 November 2017

Final Accepted: 08 December 2017

Published: January 2018

Keywords:-

Okra, Direct effect, Indirect effect.

\section{Abstract}

The study on direct and indirect effects of thirteen different quantitative characters of okra had revealed the presence of very high direct positive effect of days to first flowering on yield plant ${ }^{-1}$. The traits viz., plant height, nodes plant ${ }^{-1}$, fruit weight, number of fruits plant ${ }^{-1}$, nodes at which first flower appeared and duration of fruiting were identified as the important yield determinants through path co-efficient analysis and these traits could be relied upon for selection of high yielding genotypes in okra. The indirect effect of days to first flowering, duration of fruiting, fruit weight, nodes plant $^{-1}$ and plant height were also found to be positive, indicating their importance in exercising selection.

Copy Right, IJAR, 2017,. All rights reserved.

\section{Introduction:-}

Okra[Abelmoschus esculentus (L.) Moench] commonly known as lady's finger is an important short duration vegetable crop, cultivated in an area of 231 thousand ha with a total production of 6350 thousand tons and a productivity of 27.5 in our country (NHB, 2012-13). Vegetables form an integral part of a balanced diet as they are rich in vitamins, minerals and antioxidants. India had the credibility of producing 162.18 million tons of vegetables in 2012-13 (NHB, 2012-13) being the second among the vegetable producing country in the world. The demand for okra variety than the existing ones is always desired for the attributes like higher yield, more number of fruits, high fruit weight, good size fruits, earliness and resistant to diseases and pests. For selection of any desire genotype for a given environment partioning the association of various yield contributing traits into direct and indirect effects to understand the relative importance of each trait that influences the yield becomes essential. Crop improvement through conventional breeding requires an insight into the magnitude of direct and indirect effects of yield component present in a crop species as it forms the basis of effective selection and hence, the present study on path co-efficient analysis in okra was taken up.

\section{Research Methods:-}

Studies were taken up involving thirty three germplasm of okra [Abelmoschus esculentus (L.) Moench] at All India Co-ordinated Research Project on Vegetable Crops, HRS, Orissa University of Agriculture and Technology, Bhubaneswar, during kharif 2013. The soil of the experimental field was sandy loam (Sand-75.24\%, Silt-14.76\%, Clay-10.76\%) and total of 33 genotypes including varieties (Arka Anamika and Pusa Sawani) was used for the study. The accessions were collected from the Indian Institute of Vegetable Research (IIVR), Varanasi for the study. The observations were recorded on five randomly selected plants per replication for each genotype on thirteen 
important quantitative characters. The direct and indirect effects were obtained by the method suggested by Dewey and $\mathrm{Lu}(1959)$.

\section{Research Findings:-}

In order to find out the cause and effect relationship on yield per plant, path co-efficient analysis was carried out taking 13 quantitative traits in Okra. The correlation of fruit yield per plant with other characters were partitionised into component of direct and indirect effects that would reflect on the nature of these association and relative importance of the components in determining fruit yield. The phenotypic correlation co-efficient was used in path analysis and the results (phenotypic path) are presented in Table 1.

Phenotypic path analysis (Table-1), revealed that days to first flowering had the highest positive direct effect (0.624) on fruit yield per plant followed by duration of fruiting (0.611). Positive direct effect were also observed for fruit weight (0.483), nodes per plant (0.412), plant height (0.290), number of fruits per plant $(0.059)$ and node at which first flower appeared (0.028). Rest of characters showed negative direct effect being highest in fruit length (-0.852) followed by days to first harvest $(-0.348)$, days to $50 \%$ flowering $(-0.269)$, fruit girth $(-0.243)$ and number of disease infected plant $(-0.242)$.

Days to first flowering had the highest positive direct effect (0.624) on fruit yield per plant. This indirect highest effect were mainly resulted by positive indirect effect via nodes per plant (0.215), fruit girth (0.059), number of fruits per plant (0.013), nodes at which first flower appeared (0.021), duration of fruiting $(0.068)$ and number of disease infected plant (0.082). The indirect effect of days to first flowering via plant height (-0.022), fruit length ($0.225)$, fruit weight $(-0.015)$, days to $50 \%$ flowering $(-0.214)$ and days to first harvest $(-0.262)$ were in negative direction.

Fruit length showed the highest negative direct effect $(-0.852)$. The indirect effect of fruit length via node at which first flower appeared (-0.003), days to 50\% flowering (-0.036) and days to first harvest $(-0.047)$ were in negative direction while rest of the characters like plant height (0.242), nodes per plant (0.309), fruit girth (0.070), fruit weight (0.239), number of fruits per plant $(0.017)$, duration of fruiting $(0.387)$, days to first flowering $(0.165)$, number of disease infected plants $(0.110)$ were found to exert positive indirect effect.

Duration of fruiting showed high positive direct effect (0.611) which was mainly contributed by indirect positive via plant height (0.101), nodes per plant (0.348), fruit girth (0.047), number of fruits per plant (0.023), days to first flowering (0.070) and number of disease infected plant (0.040). The indirect effect of duration of fruiting was in negative direction via fruit length $(-0.541)$, fruit weight $(-0.054)$, node at which first flower appeared $(-0.003)$, days to $50 \%$ flowering (-0.059) and days to first harvest $(-0.110)$.

Fruit weight showing positive direct effect (0.483) exhibited indirect positive effect via plant height (0.197), nodes per plant (0.239), number of fruits per plant (0.015), days to 50\% flowering (0.018), days to first harvest (0.030) and number of disease infected plant (0.038) while for rest of the characters like fruit length $(-0.421)$, fruit girth (-0.056), node at which first flower appeared (-0.002), duration of fruiting (-0.069) and days to first flowering $(-0.019)$, the effect was on negative direction.

Other characters such as nodes per plant (0.412), plant height (0.290) and number of fruits per plant (0.059) showed positive direct effect being lowest in node at which first flower appeared (0.028). The lowest positive direct effect for node at which first flower appeared was due to negative indirect effect via plant height (-0.098), fruit weight ($0.044)$, number of fruits per plant (-0.007), duration of fruiting (-0.069), days to $50 \%$ flowering (-0.249) and days to first harvest $(-0.135)$, in spite of positive indirect effect via other traits for this character.

The negative direct effect of fruit girth (-0.243) was via the negative indirect effect of nodes per plant, number of fruits per plant, node at which first flower appeared, duration of fruiting, days to first flowering and number of disease infected plant, in spite of positive indirect effect by rest of the characters among which fruit length (0.237) was higher magnitude. 
Table 1:- Estimate of direct (diagonal) and indirect effect of component characters on yield in okra germplasm

\begin{tabular}{|c|c|c|c|c|c|c|c|c|c|c|c|c|c|}
\hline $\begin{array}{c}\text { Characte } \\
\text { rs }\end{array}$ & $\mathbf{P H}$ & $\mathbf{N P}$ & FL & FG & FW & NF & $\begin{array}{c}\text { NF } \\
\text { F }\end{array}$ & $\begin{array}{c}\text { DO } \\
\text { F }\end{array}$ & $\begin{array}{c}\text { DFF } \\
\mathbf{L}\end{array}$ & DF & $\begin{array}{c}\text { DF } \\
\mathbf{H}\end{array}$ & $\begin{array}{c}\text { No. of } \\
\text { diseas } \\
\text { e } \\
\text { infecte } \\
\text { d } \\
\text { plants }\end{array}$ & $\begin{array}{l}\text { Phenotyp } \\
\text { ic } \\
\text { correlati } \\
\text { on with } \\
\text { yield }\end{array}$ \\
\hline $\mathrm{PH}$ & $\frac{0.29}{\underline{0}}$ & $\begin{array}{c}0.29 \\
6\end{array}$ & $\begin{array}{c}- \\
0.71 \\
1\end{array}$ & $\begin{array}{c}- \\
0.02 \\
4\end{array}$ & $\begin{array}{c}0.32 \\
8\end{array}$ & $\begin{array}{c}0.03 \\
3\end{array}$ & $\begin{array}{c}- \\
0.00 \\
9\end{array}$ & $\begin{array}{c}0.21 \\
3\end{array}$ & $\begin{array}{c}- \\
0.049\end{array}$ & $\begin{array}{c}0.09 \\
2\end{array}$ & $\begin{array}{c}- \\
0.04 \\
8\end{array}$ & 0.138 & 0.340 \\
\hline NP & $\begin{array}{c}0.20 \\
8\end{array}$ & $\frac{0.41}{\underline{2}}$ & $\begin{array}{c}- \\
0.64 \\
0\end{array}$ & $\begin{array}{c}0.09 \\
8\end{array}$ & $\begin{array}{c}0.28 \\
0\end{array}$ & $\begin{array}{c}0.05 \\
8\end{array}$ & $\begin{array}{c}0.00 \\
2\end{array}$ & $\begin{array}{c}0.51 \\
5\end{array}$ & 0.326 & $\begin{array}{c}- \\
0.08 \\
8\end{array}$ & $\begin{array}{c}- \\
0.26 \\
7\end{array}$ & 0.138 & 0.504 \\
\hline FL & $\begin{array}{c}0.24 \\
2\end{array}$ & $\begin{array}{c}0.30 \\
9\end{array}$ & $\frac{\overline{\bar{z}}}{\underline{0.85}}$ & $\begin{array}{c}0.07 \\
0\end{array}$ & $\begin{array}{c}0.23 \\
9\end{array}$ & $\begin{array}{c}0.01 \\
7\end{array}$ & $\begin{array}{c}- \\
0.00 \\
3 \\
\end{array}$ & $\begin{array}{c}0.38 \\
7\end{array}$ & 0.165 & $\begin{array}{c}- \\
0.03 \\
6 \\
\end{array}$ & $\begin{array}{c}- \\
0.04 \\
7 \\
\end{array}$ & 0.110 & 0.277 \\
\hline$\overline{F G}$ & $\begin{array}{c}0.02 \\
8\end{array}$ & $\begin{array}{c}- \\
0.16 \\
6\end{array}$ & $\begin{array}{c}0.23 \\
7\end{array}$ & $\frac{0 . \overline{2} 4}{\underline{3}}$ & $\begin{array}{c}0.11 \\
3\end{array}$ & $\begin{array}{c}- \\
0.02 \\
4\end{array}$ & $\begin{array}{c}- \\
0.00 \\
8\end{array}$ & $\begin{array}{c}- \\
0.11 \\
8\end{array}$ & $\begin{array}{c}- \\
0.153\end{array}$ & $\begin{array}{c}0.11 \\
1\end{array}$ & $\begin{array}{c}0.11 \\
8\end{array}$ & -0.093 & 0.005 \\
\hline FW & $\begin{array}{c}0.19 \\
7\end{array}$ & $\begin{array}{c}0.23 \\
9\end{array}$ & $\begin{array}{c}- \\
0.42 \\
1\end{array}$ & $\begin{array}{c}- \\
0.05 \\
6\end{array}$ & $\frac{0.48}{\underline{3}}$ & $\begin{array}{c}0.01 \\
5\end{array}$ & $\begin{array}{c}- \\
0.00 \\
2\end{array}$ & $\begin{array}{c}- \\
0.06 \\
9\end{array}$ & $\begin{array}{c}- \\
0.019\end{array}$ & $\begin{array}{c}0.01 \\
8\end{array}$ & $\begin{array}{c}0.03 \\
0\end{array}$ & 0.038 & 0.242 \\
\hline $\mathrm{NF}$ & $\begin{array}{c}0.16 \\
1\end{array}$ & $\begin{array}{c}0.40 \\
1\end{array}$ & $\begin{array}{c}- \\
0.24 \\
5\end{array}$ & $\begin{array}{c}0.09 \\
8\end{array}$ & $\begin{array}{c}0.12 \\
8\end{array}$ & $\frac{0.05}{\underline{9}}$ & $\begin{array}{c}- \\
0.00 \\
3\end{array}$ & $\begin{array}{c}0.23 \\
9\end{array}$ & 0.136 & $\begin{array}{c}- \\
0.01 \\
2\end{array}$ & $\begin{array}{c}- \\
0.19 \\
6\end{array}$ & 0.144 & 0.657 \\
\hline NFF & $\begin{array}{c}- \\
0.09 \\
8\end{array}$ & $\begin{array}{c}0.02 \\
8\end{array}$ & $\begin{array}{c}0.09 \\
1\end{array}$ & $\begin{array}{c}0.07 \\
6\end{array}$ & $\begin{array}{c}- \\
0.04 \\
4 \\
\end{array}$ & $\begin{array}{c}- \\
0.00 \\
7\end{array}$ & $\frac{0.02}{\underline{8}}$ & $\begin{array}{c}- \\
0.06 \\
9 \\
\end{array}$ & 0.476 & $\begin{array}{c}- \\
0.24 \\
9\end{array}$ & $\begin{array}{c}- \\
0.13 \\
5 \\
\end{array}$ & 0.044 & 0.015 \\
\hline DOF & $\begin{array}{c}0.10 \\
1\end{array}$ & $\begin{array}{c}0.34 \\
8\end{array}$ & $\begin{array}{c}- \\
0.54 \\
1\end{array}$ & $\begin{array}{c}0.04 \\
7\end{array}$ & $\begin{array}{c}- \\
0.05 \\
4\end{array}$ & $\begin{array}{c}0.02 \\
3\end{array}$ & $\begin{array}{c}- \\
0.00 \\
3\end{array}$ & $\frac{0.61}{\underline{1}}$ & 0.070 & $\begin{array}{c}- \\
0.05 \\
9\end{array}$ & $\begin{array}{c}- \\
0.11 \\
0\end{array}$ & 0.040 & 0.240 \\
\hline DFFL & $\begin{array}{c}- \\
0.02 \\
2\end{array}$ & $\begin{array}{c}0.21 \\
5\end{array}$ & $\begin{array}{c}- \\
0.22 \\
5\end{array}$ & $\begin{array}{c}0.05 \\
9\end{array}$ & $\begin{array}{c}- \\
0.01 \\
5\end{array}$ & $\begin{array}{c}0.01 \\
3\end{array}$ & $\begin{array}{c}0.02 \\
1\end{array}$ & $\begin{array}{c}0.06 \\
8\end{array}$ & 0.624 & $\begin{array}{c}- \\
0.21 \\
4\end{array}$ & $\begin{array}{c}- \\
0.26 \\
2\end{array}$ & 0.082 & 0.056 \\
\hline $\mathrm{DF}$ & $\begin{array}{c}- \\
0.09 \\
9 \\
\end{array}$ & $\begin{array}{c}0.13 \\
5\end{array}$ & $\begin{array}{c}- \\
0.11 \\
6 \\
\end{array}$ & $\begin{array}{c}0.10 \\
0\end{array}$ & $\begin{array}{c}- \\
0.03 \\
3 \\
\end{array}$ & $\begin{array}{c}0.00 \\
2\end{array}$ & $\begin{array}{c}0.02 \\
6\end{array}$ & $\begin{array}{c}0.13 \\
5\end{array}$ & 0.497 & $\frac{0 .}{\underline{0.26}}$ & $\begin{array}{c}- \\
0.24 \\
5\end{array}$ & 0.046 & 0.047 \\
\hline DFH & $\begin{array}{c}0.04 \\
0\end{array}$ & $\begin{array}{c}0.31 \\
6\end{array}$ & $\begin{array}{c} \\
0.11 \\
7\end{array}$ & $\begin{array}{c}0.08 \\
3\end{array}$ & $\begin{array}{c}- \\
0.04 \\
2\end{array}$ & $\begin{array}{c}0.03 \\
3\end{array}$ & $\begin{array}{c}0.01 \\
1\end{array}$ & $\begin{array}{c}0.19 \\
4\end{array}$ & 0.470 & $\begin{array}{c}- \\
0.18 \\
9\end{array}$ & $\frac{0 . \overline{\overline{3}} 4}{\underline{8}}$ & 0.105 & 0.177 \\
\hline $\begin{array}{c}\text { No. of } \\
\text { disease } \\
\text { infected } \\
\text { plants }\end{array}$ & $\begin{array}{c}- \\
0.16 \\
5\end{array}$ & $\begin{array}{c}- \\
0.23 \\
5\end{array}$ & $\begin{array}{c}0.38 \\
8\end{array}$ & $\begin{array}{c}- \\
0.09 \\
3\end{array}$ & $\begin{array}{c}- \\
0.07 \\
6\end{array}$ & $\begin{array}{c}- \\
0.03 \\
5\end{array}$ & $\begin{array}{c}- \\
0.00 \\
5\end{array}$ & $\begin{array}{c}- \\
0.10 \\
1\end{array}$ & $\begin{array}{c}- \\
0.211\end{array}$ & $\begin{array}{c}0.05 \\
2\end{array}$ & $\begin{array}{c}0.15 \\
1\end{array}$ & -0.242 & -0.287 \\
\hline
\end{tabular}

Residual effect $=0.4452013$

Figures underlined denoted the Direct Effect
$\mathrm{PH}=$ Plant height $\quad \mathrm{FW}=$ Fruit weight
DFFL = Days to first flowering
$\mathrm{DFH}=$ Days to first harvest
$\mathrm{NP}=$ nodes per plant $\quad \mathrm{NF} \quad=$ No. of fruits/plant
$\mathrm{DF} \quad=$ Days to $50 \%$ flowering
DOF $=$ Duration of fruiting
FL $=$ Fruit length $\quad$ NFF $=$ Node at which first flower appeared $\quad F G=$ Fruit girth 


\section{Discussion:-}

The phenotypic path coefficient analysis revealed that days to first flowering, duration of fruiting, fruit weight and nodes per plant had maximum direct effect on fruit yield of okra. Further, plant height, number of fruits per plant and node at which first flower appeared also produced positive direct effect of lower magnitude. On the other hand, fruit girth, days to first harvest, days to $50 \%$ flowering and number of disease infected plant had negative direct effect on yield being highest in fruit length. The low positive or negative direct effect resulted due to cancellation by the respective indirect effects via days to first flowering, duration of fruiting fruit weight and nodes per plant.

The indirect effect of days to first flowering via nodes per plant, fruit length, days to $50 \%$ flowering and days to first harvest thus producing high positive direct effect for these characters. Similarly duration of fruiting, fruit weight and number of nodes per plant has the highest direct effect which is mainly contributed by the positive indirect effect via nodes per plant and plant height, nodes per plant and plant height, duration of fruiting and plant height respectively. The findings are in agreement with Dhankhar and Dhankhar (2002) who reported indirect contribution of plant height towards yield. Kiran Patro and Ravisankar (2004) reported high positive direct effect for fruit weight, nodes per plant and plant height towards okra similar to present findings. Further, Alam and Hossain (2008), Adiger et al.(2011), Reddy et al.(2013), Yonas et al.(2014) also reported direct and indirect effect of various characters like nodes per plant, fruit weight, plant height, days to $50 \%$ flowering on fruit yield of okra similar to present findings.

On the basis of foregoing discussion it may be inferred that days to first flowering, duration of fruiting, fruit weight and nodes per plant had considerable direct contribution to fruit yield in okra. High indirect effect to these traits are also observed. This clearly indicates that direct selection for these characters would be beneficial for improvement in fruit yield of okra since all these characters also show positive correlation with fruit yield. Other characters which had shown significant correlation with fruit yield per plant are mainly due to indirect effect via these characters.

\section{References:-}

1. Adiger, S., Shanthakumar, G., Gangashetty, P.I. and Salimath, P.M. (2011). Association studies in okra [Abelmoschus esculentus (L.) Moench]. Elec. J. Pl. Breed., Dec, 2 (4): 568-573.

2. Alam, A. K. M. A. and Hossain, M. M., (2008). Variability of different growth contributing parameters of some okra (Abelmoschus esculentus L.) accessions and their interrelation effects on yield. Journal of Agriculture and Rural Development, 6(1 \& 2): 25-35.

3. Dewey, D.R. and Lu, K.H. (1959). Correlation and path analysis of components of crested wheat grass seed production. Agron. J., 51 (9): 515-518.

4. Dhankhar, B.S. and Dhankhar, S.K. (2002). Genetic variability, correlation and path analysis in okra [Abelmoschus esculentus (L.) Moench]. Veg. Sci., 29 (1): 63-65.

5. Jagan. K., Reddy, K. R., Sujatha, M., Sravanthi, V.and Reddy, S. M., (2013). Studies on genetic variability, heritability and genetic advance in okra (Abelmoschus esculentus (L.) Moench). IOSR Journal of Agriculture and Veterinary Science, 5 (1), Sept-Oct: 59-61.

6. Kiran Patro T.S.K.K. \& Ravisankar C., (2004). Genetic variability and multivariate analysis in okra (Abelmoschus esculentus (L.) Moench). Tropical Agriculture Research, 16: 99-113.

7. Yonas Mihretu, Weyessa Garedew and Adugna Debela, (2014). Variability and association of quantitative characters among okra (Abelmoschus esculentus (L.) Moench). Journal of Biological Sciences, 14 (5): $336-342$. 